ESID Working Paper No. 109

\title{
Social protection in an electorally competitive environment (1): The politics of Productive Social Safety Nets (PSSN) in Tanzania
}

Thabit Jacob ${ }^{1}$

Rasmus Hundsbæk Pedersen ${ }^{2}$

November 2018

${ }^{1}$ Department of Social Sciences and Business, Roskilde University and University of Dodoma

Email correspondence: thabit@ruc.dk

${ }^{2}$ Danish Institute for International Studies (DIIS) and Department of Social Sciences and Business, Roskilde University

Email correspondence: rhp@diis.dk

ISBN: 978-1-912593-11-8 


\begin{abstract}
Social protection has become a more important part of social service delivery in Tanzania over the last couple of decades. This paper analyses the politics behind the making and implementation of the Productive Social Safety Nets (PSSN), a cash transfer scheme that became part of a broader, existing scheme aimed at poverty reduction and rural development, TASAF I-III. We trace the interrelationship between the domestic policy process and the shifting influence of transnational ideas. We argue that the introduction of TASAF and later PSSN was strongly influenced by international trends, driven by a policy coalition of bureaucrats and development partners, but that it was sanctioned by the country's political elites, who at times used the programmes for electoral purposes. This happened for instance by influencing the scale and speed of PSSN's implementation prior to the national elections in 2015, despite a tradition of scepticism towards cash transfers within the ruling CCM party. Recently, President John Magufuli's more productivist ethos, emphasising the importance of work, poses a threat to the programmes' continuation. This may also reduce the targeting of the poorest of the poor, which constitutes a major element of PSSN as we know it.
\end{abstract}

Keywords: Tanzania, social protection, cash transfer, productive social safety nets, electoral politics, ideas, political settlement, process tracing

Jacob, T. and Hundsbæk Pedersen, R. (2018) Social protection in an electorally competitive environment (1): The politics of Productive Social Safety Nets (PSSN) in Tanzania. ESID Working Paper No. 109. Manchester, UK: The University of Manchester. Available at www.effective-states.org

This document is an output from a project funded by UK Aid from the UK government for the benefit of developing countries. However, the views expressed and information contained in it are not necessarily those of, or endorsed by the UK government, which can accept no responsibility for such views or information or for any reliance placed on them. 


\section{Introduction}

Social service delivery has a long history in Tanzania. The colonial authorities launched various kinds of intervention, however limited and differentiated, to shield the population from social events. At independence, disease, ignorance and poverty were declared the main targets of development policies, leading to major improvements in access to basic education and health services. Since then, state interventions have ebbed and flowed with the design of economic development models. During the economic downturn, as African socialism broke down, and during the early years of liberalisation, the improvements in accessing services came to a halt and in some instances went into reverse. Subsequently, over the last three decades, a host of reforms in different sectors have been aimed at repairing dysfunctional service delivery systems, mostly in collaboration with development partners and in some instances being driven by them. Often, when combined with improved economic conditions and the advent of a more resourceful state, this has led to innovation and improvements. Social protection - that is, 'measures to protect livelihoods and wellbeing' that go beyond basic social services (Marcus et al., 2004) - has thus become more important.

However, reforms rarely go uncontested. Different stakeholders will seek to influence their design, as well as their implementation. Furthermore, one may ask, who do such reforms target? Though often technical in nature, there is a political economy to most reforms, which produces winners and losers. For instance, when health-sector reforms were initiated in the early 1990s, studies had demonstrated that the existing system was biased in favour of the wealthy urban population at the expense of the rural poor (Abel-Smith and Rawal, 1992). What, then, are the political and institutional factors that decide reform outcomes? This is the first of two papers addressing these questions, based on empirical research in mainland Tanzania. ${ }^{1}$ It provides the overall introduction, the historical background, outlining the political dynamics shaping policies and implementation, as well as the first case study, the Productive Social Safety Nets (PSSN) - a cash transfer programme that was part of a broader scheme aimed at poverty reduction and rural development, TASAF III, which was rolled out from 2012 onwards. The second paper, 'Social protection in an electorally competitive environment (2): The politics of health insurance in Tanzania'(Pedersen and Jacob, 2018, forthcoming), provides the second study on the introduction of health insurances.

This paper draws on the 'political settlement' approach that provides a structured analysis of the pattern of power, institutions and distribution of resources in society (Di John and Putzel, 2009; Khan, 2010), which links to issues of structural economic transformation, often with a focus on the material interests of different elite factions. In our case, the studies are part of the sub-theme on social provisioning, which draws on an adapted framework by Tom Lavers and Sam Hickey, in order to analyse social protection in low-income developing countries (Lavers and Hickey, 2016). The latter

\footnotetext{
${ }^{1}$ Zanzibar, which has been part of a union with the Tanzanian mainland since 1964, has its own social protection policies, and will not be included.
} 
highlights the importance of paradigmatic ideas, transnational influences and policy coalitions, each of which may help shape social protection policies. Though the three are analytically distinct, they often overlap in practice. This also means that it is statelevel interventions that are at the core of the analysis, not the informal or improvised schemes that nonetheless remain important in most African contexts (Maclean, 2010; Awortwi, 2018).

Overall, the papers suggest that both the introduction of PSSN and health insurances mirrored international trends at the time of introduction, but that the design of interventions and the speed of their implementation are decisively influenced by Tanzania's political economy. It is not uncommon to depict reforms as having been imposed on Tanzania (for a health-sector example, see Chimhutu et al., 2015), and indeed the influence of international development partners is undeniable in both sectors. A reform coalition of bureaucrats and development partners has often been driving the development of reforms and policy interventions. Governments were more focused on improving access to services for the rural majority, but they accepted social protection proposals as long as they were not directly opposed to their priorities and helped keep donor money flowing. However, major reforms were rarely, if at all, designed and implemented withouth the blessing of the very top of the Tanzanian political system. The sped-up implementation of PSSN, with payouts to millions in the run-up to the 2015 elections, furthermore, is hard not to see as being advantageous for a CCM party under pressure by what turned out to be historically competitive elections.

In contrast to Ulriksen's (2016) emphasis on 'ideas' and policy entrepreneurs, in the form of a coalition between bureaucrats and development donors driving change, the present analysis thus identifies electoral and power politics controlled by the ruling politicians as being no less important in shaping programmes and their implementation. This is strongly linked to the political dynamics in Tanzania, where electoral competition became steadily tougher with the reintroduction of multiparty elections in 1994-95 and in particular with the 2010 elections onwards, when a stronger and better organised opposition gradually emerged. This pushed the ruling party increasingly to return to its roots of service delivery by targeting the rural majority, which it had never given up on rethorically, but often not implemented in practice. The political value of organising social programmes for local-level politicians and bureaucrats, until recently almost completely dominated by the ruling Chama Cha Mapinduzi (CCM) party, should not be underestimated, especially in the early years. This does not necessarily mean that the identification of beneficiaries has been directly influenced by political affiliation (i.e. favouring ruling party voters), but the timing of implementation has at times correlated conspicously with the election cycle. More research into the political implications of implementation at the local level is needed.

With the election of a new administration after the election in 2015, there are renewed tensions over exactly how pro-poor these social protection interventions should be. This is particularly clear in the case of PSSN analysed in this paper, but 
the expansion of contributory health insurance schemes points in the same direction. Shifting government emphasis on self-reliance, for instance participation in public work programmes as a precondition for receiving the cash, has remained a constant. Whereas the unconditional cash transfer element of the PSSN was eventually accepted by the last administration prior to the last election, and ended up covering 70 percent of poor households in the country, 8-10 percent of the entire population according to a recent World Bank report, and expected to reach the remaining 30 percent before the next election in 2020 (Bakari, 2017; Beegle et al., 2018), the new president, Magufuli, seems to be returning to a more classic CCM productivist ethos that emphasises public work, community development and self-reliance as the main elements in social policy. This also means that, whereas past interventions increasingly targeted the rural poor, the most poor and vulnerable - those who cannot work - may now be losing out. These changes, furthermore, reflect wider changes in the country's political settlement, in which more statist elements are strengthened through recentralisation, which can be seen as CCM's attempt to boost its electoral strength and maintain control as the opposition has gained a foothold in many parts of the country. Traditional development partners and line ministry bureaucrats have lost out.

Tanzania is an interesting case, as it has not witnessed any of the major disruptions in the form of coups, civil wars or regime change that have characterised so many other African countries. Rather, it has had the same ruling party in different guises since mainland Tanzania gained independence in 1961. Whereas the country has pursued quite variegated policies over the years, the party has never renounced on its adherence to African socialism or the idea of universal access to basic services. Tanzania has also been the biggest major recipient of development assistance measured as a percentage of total assistance to sub-Saharan Africa, at times receiving close to 10 percent (Edwards, 2014). It thereby provides us with a case in which we can follow gradual as well as sudden changes in the country's political settlement, internal party ideas and ideology, and the influence of external ideas, often introduced by development partners, that combined are expected to shape social protection outcomes.

Methodologically this PSSN paper is informed by a process-tracing methodology, based on a review of the relevant political economy literature, combined with field research in mainland Tanzania between November 2017 and April 2018. The PSSN literature review is largely based on the work of Ulriksen (2016), who provided an 'ideational' analysis with a focus on policy entrepreneurs driving change. Fieldwork interviews focused on understanding the PSSN policymaking process and the influence of political actors, both domestic as well as development partners. This was done through semi-structured, key informant interviews with senior government bureaucrats involved in the initial design of PSSN, representatives of the donor community, technical staff working for international organisations, local researchers and consultants. It was supplemented with literature reviews of both popular and academic sources on the topic of social protection, the PSSN initiative, and broader political economy of Tanzania. 


\section{From independence to liberalisation and multiparty democracy in Tanzania: Social services with an urban bias}

Despite having had the same ruling party in power since independence in 1961, Tanzania's political settlement has evolved considerably since then. In the mid1960s, a single-party system was introduced, which cemented the vanguard party, Chama Cha Mapinduzi (CCM), ${ }^{2}$ in its control of most aspects of political and economic life in the country through its control of the state. This was reinforced by the introduction of the single-party system around 1965. In the following years, and in particular after the Arusha Declaration in 1967, which announced the advent of African socialism, the state took control of the economy through the widespread nationalisation of private enterprises and reforms of cooperatives, as well as dominating associational life through a concerted effort to control civil-society organisations, unions and religious congregations (Silver, 1984; Tripp, 2000; Kimambo et al., 1969). Even in the social sector, the state was to play a key role in breaking with the colonial past by introducing universal access to basic education and health services.

President Nyerere, who was by far the dominant figure in Tanzanian politics until liberalisation set in and the ruling party emphasised the compatibility of socialism and traditional values, coined in 1962 the Swahili term for African socialism, 'Ujamaa', with its notions of brotherhood or familyhood, the latter also referring to traditional African families in which you had obligations to take care of each other (Bienen, 1967; Hyden, 1975; Havnevik and Isinika, 2010). Disappointed by the development model that had been pursued since independence, which had aimed at attracting FDI and aid, Nyerere increasingly emphasised the importance of socialism and selfreliance, 'Ujamaa na Kujitegemea'. He did not oppose aid, but emphasised that the main impetus should come from within, also in the light of recent aid cuts by major development donors (Kimambo et al., 2017). TANU's Policy on Socialism and SelfReliance (the Arusha Declaration), therefore stressed the value of hard work as the main impetus for development. It also re-emphasised the importance of rural and agricultural development (Nyerere, 1967; Cliffe, 1967; Kimambo et al, 2017).

Ironically, development aid skyrocketed after the passing of the Arusha Declaration. It was driven by a combination of a number of donors being sympathetic to Nyerere's programme and their own interest in keeping Tanzania - being strategically important as a frontline state in the Cold War - as a partner that did not align with the other block (Edwards, 2014). Still, to a large extent it became a more radical approach to modernisation, in which industrialisation and forced villagisation was pursued, pushed by a faction that had been strengthened by the union agreement entered into with the revolutionary government Zanzibar in 1964. Similarly, despite strong propoor rhetoric and policies targeting the rural population, the implementation and

2 At independence, the Tanganyika African National Union (TANU) won elections overwhelmingly. In 1964, Tanganyika entered a union with Zanzibar after a revolution on the islands, and in 1977 the ruling parties merged to form Chama Cha Mapinduzi (CCM), the party of the revolution. 
distributional impact was ambiguous, to put it mildly. Whereas the Arusha Declaration of 1967 had emphasised ownership of the means of production by farmers and workers, actual interventions often benefited the urban middle classes (Mukandala, 1989, Morrissey and Leyaro, 2009. See also Bates 1981).

The economy began declining in the early 1970s, but it was not until the end of the decade, after a series of external shocks, that negotiations with IMF over structural adjustment began. However, only in 1986, after drawn-out negotiations and even walkouts, did the Tanzanian government and IMF reach an agreement after intense pressure from development donors. By then, aid had declined from USD702 million in 1981 to USD487 million in 1985. Initial reforms were aimed at liberalising the economy and increasing macro-economic stability, and in the mid-1990s they were followed by a wave of privatisations. Though the private sector was never completely abolished during the era of African socialism, it now gained a prominent role in Tanzania's development, most conspicuously demonstrated by the revision of the Arusha Declaration in 1991, which allowed and encouraged party members to engage in private-sector activities (Gibbon, 1995).

The advent of structural adjustment coincided with the departure of the country's leader since independence, Julius Nyerere, who retired as president in 1985, unwilling to give in to IMF, but also realising that change was required. His successor, President Mwinyi, was reform-minded, but struggled to implement his economic agenda of liberalisation due to internal resistance in the party, still chaired by Nyerere, and the bureaucracy (Edwards, 2014; Lofchie, 2014). This fracturing signified a weakening in the control of the ruling party compared to previously.

In terms of social policies, the independence government had inherited a rather fragmented system, which to a large extent targeted different ethnic groups, but with very limited services being provided to the large African majority population. In education, European and Asian children received far more and far better schooling. The health sector consisted of traditional healers, a few clinics and missionary health centres. Upon independence, the first leader, Prime Minister and later President Julius Nyerere, declared poverty, disease and ignorance the three 'major enemies of development' (Lugalla, 1993, Morrisson, 2002, Bech et al., 2013). A main priority of the party and government was to create a system of universal access to services. Health and education were indeed priorities in the five-year plans which shared a major element of expanding physical infrastructure across the country to improve access to services through the construction of village-level primary schools and village health institutions in particular. These were often constructed by the villagers themselves, who then asked the government to step in and fund drugs and staff (Munishi, 1995; URT, 1990). The Ujamaa villagisation programme was also meant to increase access to social services by moving people to village centres.

In terms of social protection, there was a greater degree of continuation from the colonial era. During villagisation, in order to prevent famine, there were schemes for the planting of certain acreages of crops, now combined with communal self-help 
efforts. Much of this was increasingly compulsory, as people were required to move to the designated Ujamaa villages to qualify for food and services, justified by the party's leaders, who often depicted peasants as 'lazy' (Ingle, 1970; Schneider, 2006; Bjerk 2017). Perceived laziness was also an issue, when some parliamentarians in 1973 worried that villagers were getting too much from the government and stressed that in the light of the policy of socialism and self-reliance, they should be doing more themselves (Hyden, 1975). In some ways, Ujamaa villagisation can be seen as a continuation of trends under colonialization, in that it forcefully created 'communities' where they may not have existed or may have existed in very different forms previously, often assisted by international NGOs, who supported what was then perceived as a progressive development agenda (Schneider, 2004; Jennings, 2008). The villagers themselves, on the other hand, often ignored the advice of the bureaucrats and party leaders, knowing that the latter's experiments could lead to food insecurity. As Ujamaa was abandoned, this led to increasingly diversified selforganised social measures, combined with the advent of humanitarian NGOs operating with tax exemptions and occasional state relief efforts in cases of drought and hunger (Hyden, 1975; Hyden, 1990; Cooksey, 2011).

In the health sector, the advent of African socialism implied a ban on deriving profit from healthcare. During the 1970s, the government began nationalising hospitals, the major exceptions being that most religious and parastatal facilities - which made up a large element in the entire healthcare system - could continue providing healthcare and charge small fees set by the government (Mbekeani, 2009; Jennings, 2015). Government health expenditure fluctuated significantly during the period, from 8.9 percent of total spending in 1973-74 after a TANU decision to prioritise health services in rural areas, only to drop to 5.6 percent five years later. Development partners played an important part in financing the health sector, covering 40-50 percent of health expenditures in the first decades of post-independence (Munishi, 1997). Despite their significant contributions, however, there seems to have been less interference by developlement partners policy-wise when compared to the later phases of liberalisation.

\section{Political adjustment to increasingly competitive elections from 1995 onwards: Liberalisation and expansion of social services}

The adoption of multiparty democracy in 1992 and the first multiparty general elections in 1995 fundamentally changed the political dynamics in the country. In the interregnum, the majority of donors suspended aid disbursement in 1994, tired of corruption and delays in the implementation of the liberalising reforms (Edwards, 2014). Only after mediation did an informal 'grand bargain' emerge, in which the government accepted progress in the implementation of reforms and donors accepted that they should apply a more hands-off approach in their dealings with domestic affairs to increase Tanzanian ownership (Lofchie, 2014). This subsequently gave the new president, the reform-minded and market-friendly Benjamin Mkapa, who was elected in 1995, a freer hand to pursue and implement reforms, even if traditionalists remained part of the party. Though he never openly criticised the 
policies of African socialism and self-reliance, he emphasised good relations with development partners and the importance of foreign direct investment (FDI) (Edwards, 2014).

In contrast to the early phases of liberalisation, however, these elements were increasingly coupled with reforms of social services that aimed at improving coverage and quality and expanding social protection elements. Mkapa's Vision 2025 was an exercise in persuading the Tanzanian population that it is better to go through the hardship of economic reform than to introduce a change in direction. It stated that the sense of stagnation and decline in terms of eradicating poverty, ignorance and disease should be addressed by new interventions:

'Ideally, a nation's development should be people-centred, based on sustainable and shared growth and be free from abject poverty. For Tanzania, this development means that the creation of wealth and its distribution in society must be equitable and free from inequalities and all forms of social and political relations which inhibit empowerment and effective democratic and popular participation of social groups...' (URT, 2000b).

An alliance between reformers, development partners, FDI and private Tanzanian businessmen emerged that led to the continued liberalisation of the economy and the reform and decentralisation of public services.

Generally, the advent of multiparty politics thus created new impulses for the political elite to balance between liberalisation that inflicted short-term hardship on the population, on the one hand, and expansion of social services that could ameliorate the pain and help win elections, on the other. A gradual, but systematic expansion ensued of physical health and education infrastructure that was popular in rural areas. A number of policies and interventions were initiated in the following years, targeting the rural majority of the population, which tended to remain staunch CCM supporters. For instance, even though the main focus of the $2000 \mathrm{CCM}$ election manifesto was on the economy, free primary education was also promised during campaigns the same year, a return to the CCM's pre-structural adjustment policies. As will become clear in the case studies on PSSN and health insurance, this coincided with a similar shift in global donor priorities, where the Millennium Development Goals and poverty reduction strategies provided new avenues for social interventions.

Free primary education was also included in the first poverty reduction strategy from the same year, which led to the construction of nearly 30,000 new classrooms in the following years and a massive increase in school enrolments (Mkapa, 2002; Vavrus and Moshi, 2009; Nyaluke and Connolly, 2013). From 1998 to 2008, net primary school enrolment increased from less than 60 percent to well above 90 percent, though one should bear in mind that this did not necessarily translate into quality education (Carlitz, 2011; Ade et al., 2013). Interestingly, this happened only five years after the finalisation of the Education and Training Policy in 1995, which had 
emphasised the importance of the private sector and of cost-sharing as ways to improve the sector (URT, 1995). These trends continued in the context of the most recent elections. Hugely popular was the expansion of the coverage of secondary schools under Kikwete, which led to transition rates from primary to secondary school increasing from 20.2 percent in 2006 to 53.6 percent in 2012 (Ade et al., 2013). At the most recent election, this feat provided the platform for the abolition of secondary school fees. Another policy targeting the rural electorate, though less pro-poor, was the reintroduction of fertiliser subsidies, a policy included in the 2005 manifesto and extended further prior to the 2010 elections (Kjær and Therkildsen, 2013).

In some respects, electoral politics thus helped bring the CCM back to its roots, with a focus on the rural majority of population that had been neglected - if not in words, then in practice during the later phases of African socialism. The idea of universal access to services had never left the party, though it was modified during the early years of liberalisation. It now again gained traction, supported by development partners. Government spending on health increased in the period to around 9 percent in the late 1990s and reached a peak of close to 20 percent in the mid2000s, only to stabilise at around 10 percent from the end of the 2000s (West-Slevin and Dutta, 2015; USAID, 2016). The expansion of access to health facilities became an element in the 2005 manifesto. After a reduction of funding under the early phases of liberalisation, donors now reengaged and reached the 35-50 percent ratio in the mid-2000s ${ }^{3}$ that has remained within that bracket since then (World Bank 2018). Donors also engaged more intensively in discussions about the design of the system (Pedersen and Jacob, 2018, forthcoming). Despite the intentions of Tanzanian ownership and coordination, providing the bigger part of the funding for the sector made them quite influential in developing the sector.

Whereas Vision 2025 did emphasise the importance of getting rid of the 'donor dependency syndrome', in practice it did not challenge the role of development partners and the sometimes tension-ridden policy-making processes that were the outcomes of the confused authority structures associated with them. In various sectors, policy coalitions of reform-minded insiders and development partners pushed through reforms, at least on paper, though they were not always implemented. The introduction of fees and insurances in the health sector and the Tanzanian Social Action Fund and the PSSN are examples of such coalitions. A major priority of the ruling party elite seems to have been to keep the money flowing, which in practice meant accepting many development partner suggestions, often because they were aligned with the government's own priorities, but at times also because they were not in direct opposition to these priorities. Occasionally, this led and still leads to what has been termed 'reformitis', that is, multiple reforms being pursued, with limited domestic ownership and limited improvements in service delivery on the ground (Therkildsen, 2000).

\footnotetext{
${ }^{3}$ See https://data.worldbank.org/indicator/SH.XPD.EHEX.CH.ZS?locations=TZ
} 
An example of such tension-ridden policy-making was the expansion of physical health infrastructure in order to improve access, a classic CCM priority reintroduced through the ten-year Primary Health Services Development Programme (MMAM) in 2007, to the surprise and consternation of the development partners, who emphasised improvement in the quality of services over physical infrastructure, even if it had been part of CCM's 2005 election manifesto. ${ }^{4}$ ' The episode illustrates that, whereas the government gave the development partners much leeway in this period, it could push its own agenda when its own interests were affected. With a lot of unfinished structures to this day, it also shows that the election promises given by the ruling party during this period may, at times, have been more about providing conspicuous development in the form of physical infrastructure than about substantially improving access. This is very much in line with the conclusions of Kjaer and Therkildsen in relation to such electoral promises: 'identifiable with the party in power; citizens are targeted countrywide; and policy implementation aims at immediate, visible results' (Kjær and Therkildsen, 2013).

\section{A tectonic shift driven by electoral politics: The power of the rural base}

Around the time of the 2010 elections, a tectonic shift occurred in the political settlement that only became visible gradually in the years that followed. Chadema, ${ }^{5}$ which has now become the dominant opposition party in Tanzania, had been embarking on an organisational capacity-building exercise that gave it a presence at the local level throughout the country. It also managed to broaden its economic base to include a much broader section of Tanzania's businesses and middle classes (Paget, 2017). Its relentless campaign on CCM corruption scandals spurred dissatisfaction and historically competitive elections, which for the first time gave the opposition parties a strong platform in parliament. Whereas the CCM had won 70 percent of the parliamentary votes (81 percent of seats) in 2005 , this was reduced to 60 percent (74 percent of the seats) in 2010. And whereas the CCM presidential candidate at the 2005 elections, Jakaya Kikwete, had won a landslide majority of 80 percent of the votes, this was reduced to 63 percent in 2010, with the main opposition contender, Dr Wilbrod Slaa of Chadema, winning 27 percent and the candidate of the small CUF party 8 percent. For CCM, the outcome was a shock and paved the way for the gradual re-emergence of a more state-led nationalist economic development model. The implementation of this model has been in particular, propagated by the current administration as part of an evermore open courting of the rural electorate.

In 2011, after the 2010 elections, the CCM subsequently embarked on a process in which it proposed to change 'like a snake shedding its skin', a rebranding exercise famously known as 'Kujivua gamba', which included some elements of internal reforms. The major elements were (i) to bring the leadership of the party closer to the people by having the members of the party's National Executive Committee elected

\footnotetext{
${ }^{4}$ This is analysed in more detail in Pedersen and Jacob (forthcoming, 2018).

${ }^{5}$ Short for 'Chama cha Demokrasia na Maendeleo', Swahili for 'Party for Democracy and Progress'.
} 
at district instead of regional level, and (ii) to take action against corrupt leaders (Daily News, 2012; Msekwa, 2017; Tsubura, 2017; see also Mallya, 2012).

In terms of economic policy, a similar shift can be observed around or immediately after the 2010 elections. Previous CCM election manifestos and poverty reduction strategies - the main evidence for government priorities in this period - had high economic growth as their main priority and saw the private sector as its engine, to be facilitated by good governance, macroeconomic stability and limited state intervention (Selbervik, 2006). However, the reintroduction of five-year development plans in 2011 signalled a more interventionist state (URT, 2011), maintaining that, although the private sector was important, business as usual was no longer an option. This way of thinking was first implemented gradually, with the strengthening of state-owned enterprises in the extractive sector (Pedersen and Jacob, 2017); but since the 2015 election, it has been radicalised, with the revival and strengthening of state-owned enterprises (SOEs) and presidential orders that the semi-independent but state-controlled pension funds invest in industrialisation (Kamndaya, 2017).

This, we would argue, represents not only a shift in economic thinking, with less emphasis on the private sector, FDI and development assistance, but also, in the thinking on the party and its allies, and in other ways, as a deliberate attempt to reconfigure the political settlement. As will become clear in the two case studies on PSSN and health insurance, this has implications for policy-making, with a decline in the influence of Western development partners, and an even bigger focus on the plight of the rural electorate through relentless political campaigning. As mentioned, the change of thinking in CCM has been underway for some time now, but it has been reinforced by the fact that the current president, John Magufuli, was a compromise candidate without strong allies in the ruling party, something he is seeking to compensate for by building a base of his own. We identify five constituencies that help keep the contemporary ruling political elite in power in different ways. ${ }^{6}$ There is some degree of continuity in some of these constituencies across presidencies and some novelty too.

- First, the rural constituency, which also has always existed, but whose importance for CCM has increased as urban elites have abandoned the party; policy interventions increasingly target rural smallholders and artisanal miners, for instance through the redistribution of land and mining licences (Jacob and Pedersen 2018).

- Secondly, the security apparatus, which maintains the peace and stability that allow the CCM to rule. It is made up of the military, the secret service and the police and was always important for the CCM, but its role has become more

\footnotetext{
${ }^{6}$ Thus taking the political settlement framework a bit further in the light of the increased electoral competition in Tanzania. Often, political settlement analyses take the existence of various types of 'coalitions' as their analytical point of departure, whether between political and economic elites focusing on rents (Khan, 2010) or between national decisionmakers and development partners focusing on specific policies (Lavers and Hickey, 2016). However, they do not always unpack the domestic coalitions in electorally competitive environments that, we would argue, accentuate issues of regime legitimacy among the electorate.
} 
conspicuous under the current president, who does not have a background in the military himself, obviously feels insecure and is therefore openly courting the military, police and security services (Odunga, 2016; Kiganda, 2016).

- Thirdly, intellectual powerbrokers, especially from the University of Dar es Salaam, who have also previously occupied government positions, but they seem to have gained power in relation to traditional party stalwarts recently.

- Fourthly, the pension funds and state-owned enterprises, who were strengthened already under President Kikwete, starting in the extractive sectors, but who have gained more ground under Magufuli; the frequent announcements of spectacular industrialisation projects generating tens of thousands of jobs provide him with a strong campaign platform (Mpango, 2017; Daily News, 2018).

- Fifthly and finally, elites from Magufuli's home area, the Lake Zone, a completely new feature in Tanzanian politics and for the CCM, which has a strong tradition of emphasising that it is the party of the entire country, not of particular ethnicities or areas.

This also means that other actors who were previously part of the ruling coalition have lost out. The development partners have already been mentioned. Another loser is the bureaucracy into which a large degree of uncertainty has crept as people are being fired for corruption, incompetence, disobedience or a lack of qualifications compared to previously (Khan and Gray, 2006; Therkildsen and Bourguin, 2012). Furthermore, decision-making has been centralised, which has reduced the influence of bureaucrats in or affiliated with line ministries whose technocrats are often being overruled by what they perceive to be politicised decisions by the few influential men around the president. This reduces the room for reform coalitions between bureaucrats and development partners that Ulriksen (2016) had identified as driving in particular the introduction of TASAF, the forerunner to PSSN.

\section{Productive social safety nets}

\section{Introduction}

When it comes to emergency services, social services and social protection, the importance of self-reliance has been emphasised throughout Tanzania's modern history. From colonial times, state authorities have sought to help people by encouraging and at times forcing them to grow certain crops, often in communal village settings, though with uncertain effect. In the event of outbreaks of hunger, the state has an emergency system, and the authorities regularly release food aid, usually subsidised and sold at very low prices (International Federation of Red Cross and Red Crescent Societies, 2006; Sembony, 2009; Mkinga, 2013). A more formalised and targeted system began to appear in the late 1990s with the Tanzania Social Action Fund (TASAF) that combined community-driven infrastructure projects and work programme interventions. A cash transfer programme in the form of PSSNs was launched as a new part of TASAF III through pilots in the late 2000s. Implementation on a larger scale only began in 2012 . The latter move signified the 
advent of a more individualised support system that remains controversial within the ruling party to this day. From the early days of designing PSSN, some politicians have voiced concerns over the sustainability of the intervention, but in the end they gave in to the arguments, evidence and funds provided by a policy coalition of World Bank representatives and technocrats. ${ }^{7}$

The introduction of Tanzania's PSSN mirrors similar programmes elsewhere in the world, thus pointing to the influence of transnational ideas and influence, though its final design and timing display some very Tanzanian traits. Whereas most countries globally opted for unconditional cash transfers, Tanzania, along with a few other African countries, attached conditions to their schemes out of concerns over laziness (Davis et al., 2016). This provides for interesting insights into CCM priorities that will be elaborated on below. As mentioned in the paper's introduction, some of these developments have been analysed by Ulriksen by means of an 'ideational' analysis focusing on the coalition of bureaucrats and development partners who successfully propagated these interventions (Ulriksen, 2016). This paper focuses more on the power and institutions that also came to play a role in shaping development outcomes, with a particular emphasis on changes in the Tanzanian political settlement. Driven by electoral politics, TASAF and PSSN interventions increasingly appear to have been implemented not only for the sake of poor beneficiaries, but also to help maximise chances of electoral success and help CCM stay in power. Recently, furthermore, a new president and administration have been putting past achievements under pressure by questioning the cash transfer programme, generally favouring public work schemes over hand-outs, and stressing that lazy people should not expect help in the case of hunger (Citizen, 2016; Guardian, 2017). The policy coalition of development partners and technocrats has thus become less influential.

\section{TASAF: The early phases}

Internationally, social funds emerged in the late 1980s and early 1990s as responses to emergency situations, in particular to alleviate the poverty that followed structural adjustment programmes introduced over the same period. The World Bank's World Development Report from 1990 outlined a three-step strategy to assist the poor, first through using their labour, secondly through basic social services, and finally through income transfers (Reddy, 1998; Frigenti et al., 1999). However, Tanzania's version of the social funds, the Tanzania Social Action Fund, came rather late, reflecting both the rather late introduction of economic adjustment from 1986 onwards, and the slow implementation that followed due to resistance from within the ruling party. The correlation between liberalisation and social interventions like TASAF is thus no coincidence. First, it reflects a stronger transnational agenda of poverty alleviation in the late phases of liberalisation. Secondly, it represents a shift in thinking in the ruling politicians, in which the state should leave it to the private sector to create economic growth and in turn take on a stronger role in addressing the hardship experienced by people affected by reform without.

\footnotetext{
${ }^{7}$ Interview with development partner representative, 8 March 2018.
} 
TASAF I was introduced under the then President Mkapa in 2000, following a pilot phase beginning in 1999. By then, Tanzania had already been engaged in developing a poverty reduction strategy for some years, with the support of UNDP and later the World Bank, which aimed to ensure the incorporation of poverty alleviation in all development plans (Gould and Ojanen, 2005; Mkapa, 2013b). At the same time, aid modalities began being shifted to general budget support, conditional on progress on a number of poverty parameters. The development of a poverty reduction strategy was also the precondition for debt relief, a major priority of President Mkapa (Daima Associates and ODI, 2005; Holtom, 2007). Coming out of a major crisis with development partners in the mid-1990s, who, according to many in Tanzania's ruling elite, 'imposed' liberalising reforms on the country, the resolve was to implement the interventions in 'partnerships' between government and development partners. TASAF did become a part of the poverty reduction strategy financed by a World Bank credit. The programme fell under the PRSP section in addressing vulnerability, a different category than the income poverty that seemed to be the main concern of the strategy (URT, 2000a).

Even though TASAF was part of an international trend to address poverty under liberalisation, Tanzanian stakeholders emphasise that it came about on the initiative of Mkapa, who on a visit to Malawi had learned about the Malawi Social Action Fund (MASAF), which was established by President Bakili Muluzi. MASAF provided public service infrastructure, but was driven by the villagers themselves. Subsequently, Mkapa brought it up in his discussions with the World Bank, upon which it was included in the strategy (Mkapa, 2013c). The design and piloting of TASAF was done under the Planning Commission within the President's Office, which he had established when he came to power in 1995 and which also developed Vision 2025. According to one bureaucrat close to the process, an important aim of TASAF was similar to some of the social interventions in Vision 2025, namely to help 'identify the social dimension of Structural Adjustment', ${ }^{8}$ or, in other words, to convince people that the economic hardship the country was going through was worth it because it was also bringing tangible social benefits. TASAF can thus be seen as a response to the criticism of structural adjustment programmes within the country and the party. What seems to have appealed to Mkapa about the programme in Malawi was indeed its combination of poverty reduction, expansion of infrastructure for service delivery, like the construction of schools, clinics and roads, with community initiative and ownership; all were elements that appealed to core CCM values of communitycentred self-reliance, or, as the more market-minded Mkapa called it, 'selfdevelopment' (Mkapa, 2013c).

The main objective of TASAF I was to 'increase and enhance the capacities of communities and other stakeholders to prioritize, implement, and manage sustainable development initiatives and in the process improve socioeconomic services and opportunities' (World Bank, 2006). The sequencing between building community capacity and providing opportunities and services for individuals is hardly

\footnotetext{
${ }^{8}$ Interview, 17 January 2018.
} 
a coincidence, stressing that the former is more important than the latter. The biggest component by far was community development initiatives that aimed at facilitating the process of identifying and designing socioeconomic infrastructure projects within education, health, markets, water, sanitation, roads, etc. The second biggest component was the public works programme, a labour-intensive 'work as a safety-net scheme' in poor areas of country that aimed at road maintenance, afforestation, water, etc. (World Bank, 2006). The emphasis on community development furthermore made the programme quite cheap when compared to more centralised programmes in, for instance, Latin America. $^{9}$

Ulriksen describes the design of these core elements of the programme as the 'productivist' focus in TASAF interventions, linking it back to the ideas of the country's founding fathers in the early independence phase, who tended to prioritise infrastructure, service delivery and industrialisation over social policy (Ulriksen, 2016). Indeed, Mkapa stresses that

'in choosing to create a Social Action Fund, the government was not only creating a mechanism for encouraging communities to own and implement projects for their own development, but also for increasing and enhancing the capacities of communities and stakeholders to prioritise, implement, and manage sustainable development initiatives and, in the process, provide new social and economic infrastructure, including improving social services' (Mkapa, 2013c).

According to TASAF, TASAF I (2000-2005) funded more than 1,700 projects and reached 7.3 million people, and TASAF II (2005-2013) funded more than 11,000 projects and reached more 16.1 million people (TASAF, 2011).

A significant international influence can be found. In 1997 Tanzania get its first more homegrown National Poverty Eradication Strategy. The strategy appears to have been more of a vision than an implementable plan and in 2000, a Poverty Reduction Strategy Paper (PRSP) was passed, with a stronger emphasis on implementation and specific interventions in line with a new approach adopted by IMF and the World Bank in 1999 (IMF and International Development Association, 2002; Mashindano and Maro, 2011). The PRSP was tightly linked to the Highly Indebted Poor Countries (HIPC) initiative, which provided for debt relief, a main priority of President Mkapa. Whereas the establishment of TASAF was thus to some extent driven by the president himself, as part of earning a licence to implement wider macro-economic reforms from within the party and from development partners, Ulriksen observes how the management and later expansion of the programme was driven by a policy coalition of Tanzanian bureaucrats and development partners, in particular the World Bank, which was the main funder of the government, through its credits.

\footnotetext{
${ }^{9}$ Interview with bureaucrat, 17 January 2018.
} 
However, we would also argue that this does not mean that TASAF's later phases were irrelevant to the machinations of the ruling party. Throughout its existence, there have also been links to electoral politics, increasingly so as political competition increased. A telling indication of this is the fact that TASAF has remained part of the President's Office. Initially this may have been due to the fact that poverty reduction was linked to debt relief and thus touched upon relations with foreign powers. However, the dual role of the president of Tanzania as head of state and chairman of the ruling party is worth emphasising, as this gives him dual responsibility for implementing reforms for the good of the country and initiating interventions to win elections for the party. In terms of electoral logics, there was a convenient overlap between the first poverty reduction strategy - and thus TASAF - and the electoral cycle, both being introduced in the 2000 election year. The correlation did, however, allow the president and the party to campaign on promises that had been settled with development partners. The potential link to electoral politics may also be traced in the following years, as the development partner-driven poverty agenda and the country's economic development model partially decoupled from one another. Tanzania's second PRSP gained an additional emphasis on growth, its main means through which to fight poverty. This was demonstrated in its title, the National Strategy for Growth and Reduction of Poverty, or, in Swahili, MKUKUTA I, in 2005, and again in MKUKUTA II in 2010. Similarly to CCM election manifestos, they thus placed less emphasis on reaching the poor than on achieving economic growth (Selbervik, 2006; CCM, 2005, 2010 and 2015). TASAF followed the same rhythm, with gradual expansions to some extent correlating with election years. TASAF II took off in 2005 and was prolonged from 2009 to 2012, when in 2009 - a local government election year and a year before the general elections - it was decided to scale up its activities, financed by a larger World Bank credit (World Bank, 2014).

However, as should be clear, the roll-out of TASAF did not strictly follow the electoral schedule and therefore the correlation should not be exaggerated. Possibly more important in the early years, the implementation of the programme by officials and politicians at the very local level, was, at least until 2014, almost entirely dominated by CCM and thus could appear as the kind of semi-formalised patronage that has remained a part of Tanzania's local political economy throughout the years (Tidemand, 2015). In this respect, the insistence on conditionality also helped demonstrate a reciprocal relation between rulers and the ruled. At the end of TASAF I, more than 1,700 projects had been funded in Tanzania mainland and Zanzibar, which supposedly benefited 7.3 million people living in their vicinity; 113,646 persons had been engaged in public works, of which 47 percent were women. Apart from being expanded, TASAF II also had a slightly more targeted approach to reaching the rural poor, by reaching 371,250 vulnerable persons through 'income generating activities' and 13,081 persons in 'Community Based-Conditional Cash Transfers'. A total of 223,751 people, of whom 47 percent were women, took part in public work programmes, and towards the end, 11,000 projects had been funded (TASAF, 2011). Furthermore, in both phases, 20,000 or more had been members of community project committees, a position in all likelihood generating allowances for rural elites. In other words, whereas the policy coalition between bureaucrats and development 
donors was important, there were strong incentives for the ruling politicians to allow for and shape the TASAF by raising development partner funds that could be used to help win elections.

\section{TASAF III and the introduction of the Productive Social Safety Nets}

According to TASAF, the most important lessons from TASAF I and II were that coverage was still too limited when compared to demand and that the targeting of the poor could be improved through cash transfers (TASAF, 2011). In Tanzania, the cash transfer method had been designed and tested in the late 2000s, first through a pilot in three districts financed by the Japanese government, and then rolled out as an expanded pilot in these same districts through the increased World Bank credit for TASAF II in 2009. Although the technical roll-out of the cash transfer scheme was facilitated by the World Bank, it was pushed strongly by TASAF staff through testing, documenting and lobbying activities. It marked a major innovation, but the staff were and are careful to frame it as a continuation of past productive programmes. Based on these ideas and experiences TASAF III began as a new ten-year programme in 2012, with a design phase before implementation gained speed.

Overall, TASAF III continued targeting communities through (i) infrastructure interventions focusing on school, health and water facilities and (ii) livelihood grants to existing functioning community savings and investment promotion groups. The novelty in (iii) the cash transfer scheme was the more systematic individualised approach that targeted the poorest of the poor. Even though the latter part of the programme was referred to as a productive social safety net, with an emphasis on its productive element, its core is an unconditional grant of TSH10.000 (USD4.5) per month for all households that can be topped up with various conditional transfers, typically linked either to children attending school or to health interventions, such as sending children for vaccination. Public work, which had been major element of TASAF I and II, was now also integrated within PSSN, together with a livelihood support component. The strengthening of the cash transfer element thus shifted the relative importance of the support elements; whereas cash transfers had been part of TASAF II linked to income for work interventions that could include the poor (Ulriksen, 2016), public work, which would happen during off-farm and dry seasons, which caused chronic shortage of both food and cash, was now linked to the cash transfer scheme.

Initially there was no clear financing strategy, and other development partners held back, because the programme was then still being funded primarily through a World Bank credit; they worried about a lack of government ownership and thus the sustainability of the programme. However, soon the government was looking to scale up the PSSN programme from a target of reaching 275,000 households to reaching the 9.8 percent of the population living under the food poverty line and an another 5 percent in transient poverty (World Bank and NBS, 2016). By August 2015, 1.1 million households had been reached and more was to come. According to a recent World Bank publication, 8-10 percent of the entire population got covered (Beegle et 
al., 2018). Around one-third of Tanzania's villages are still not covered, but, according to government announcements, they will be covered 'before the current government tenure ends' (sic!) (Bakari, 2017; Guardian, 2018).

According to a donor representative, the expansion was influenced by the UN system, where there was a perception that Tanzania would fail to reach the Millennium Development Goal of reducing extreme poverty by half without further interventions. ${ }^{10}$ But by then the government was also becoming more optimistic about Tanzania's own revenues, as the economy was booming and there were expectations within the government that revenues from the large natural gas deposits that had been found offshore along the Indian Ocean rim would soon start flowing. This, supposedly, would allow for more social spending than previously. The decision to scale up the programme, and thus also its final design, was brought before the Cabinet for approval in 2013, because it involved another World Bank credit. By then, the government was committed to a larger element of co-financing than previously.

Under the new arrangements, the government would provide a third of the funding from its own revenues, a third was to come from a World Bank credit and a third from other development partners. Of the latter, DFID and SIDA became the biggest contributors out of a group of more than ten actors, including five UN agencies (UNICEF, WFP, ILO, UNFPA and UNDP), to provide technical assistance. The conditional cash transfer was strongly propagated by the development partners, which now had been expanded from the World Bank to include DFID, SIDA, Irish Aid, USAID, Gates Foundation and UNICEF, WFP, ILO, UNFPA and UNDP, the latter more in terms of technical assistance. In particular, the main donors, the World Bank and DFID, wanted to target the poorest of the poor, and so did, increasingly, TASAF staff. Various workshops in Tanzania and visits to Ethiopia, Rwanda and Malawi facilitated by the World Bank and DFID in the early PSSN design phase had convinced the staff about the advantages of a cash transfer programme. Some donors like DFID and UNICEF initially wanted unconditional cash transfers, but were later convinced that conditional transfers could work. Tanzania ended up with its own unique blend of conditional cash transfers with an unconditional core. Whereas in Malawi public work accounted for 90 percent of the programme, and Ethiopia and Rwanda also emphasised public work, Tanzania opted to roll out the cash transfer programme first and then gradually incorporate first the public work and then the livelihood components. The reason for this sequence was a shared feeling among donors and technocrats that designing and implementing public work programmes would require more planning, for which more capacity had to be developed first. In the end, a combination of donor technical support and ideas from local technocrats was influential in the design. ${ }^{11}$

The result looks like a compromise, as a major element of public works has been retained in TASAF III, even if the cash transfer scheme now makes up the core of the

\footnotetext{
${ }^{10}$ Interview, 19 January 2018.

${ }^{11}$ Interview with development partner representative, 8 March 2018.
} 
programme. Tanzania became one of only a few African countries to attach conditions, which are disliked by many development partners, to its cash transfer programme (Davis et al., 2016). Out of the 1.1. million PSSN recipients, 600,000 were initially expected to be in public work during the programme. In the end, all donors supported the combination of conditional cash transfers, public work and livelihood components. However, the money that the government had committed one-third of the expanded TASAF III budget - never materialised and, therefore, the programme ran out of money for this activity, reaching less than half, close to $300,000 .{ }^{12}$ The next expansion, the extension of TASAF III's first five-year phase, with another two years to 2019, was also funded through a World Bank credit and seems not to include more funding for the public work element of PSSN (World Bank, 2017).

However, under the impression of the renewed political push from State House to channel more finance to public work, the World Bank and local technocrats are trying to make an evidence-based case that CCT has transformed poor households and should continue to be the main component alongside public work. Evaluations are produced to support this view. Donors seem to prefer CCT over public work, but they are ready to go with what the government prefer, as long as the cash transfer element is maintained. As a donor representative puts it, 'I can tell you donors are very flexible, but one thing is very clear, they don't want to see cash transfers disappearing'. ${ }^{13}$ TASAF staff insist that there is even a productive element to the unconditional cash transfers, in that they provide money for food and health services, which are preconditions for the ability to work.

The reason why the policy coalition of TASAF staff and development partners emphasises the productive element of TASAF is obvious: the government did not want to be seen giving hand-outs. They therefore stressed the importance of the productive aspect of the programme already during the design phase:

'During the design of the project, that was financed by Japan, the first step you take is consultations. The response, especially from women, was that, if there were no conditions, our children would not go to school. During the second phase [of the design process, ed.] it was the government - we come from this self-reliance background, you know - that said: "if you give money and there is obligations to it, it makes sense.",14

The link to Tanzania's founding fathers' emphasis on hard work as a crucial element towards achieving self-reliance as individuals, families, communities and a nation is clear. However, the channelling of resources through local institutions that until quite recently were almost completely controlled by CCM can also be a way to emphasise a link between social benefits and the CCM government.

\footnotetext{
${ }^{12}$ Interview with development partner representative, 15 January 2018.

${ }^{13}$ Interview, 8 March 2018.

${ }^{14}$ Interview with bureaucrat, 17 January 2018.
} 


\section{CCM ambivalence about PSSN and electoral politics}

The decision to initiate TASAF in year 2000 and link it up with PSSN, the cash transfer programme, in 2012, was connected to the international poverty reduction agenda that had gained prominence, linked to the liberalisation of the economy in the late 1980s and 1990s. In Tanzania, the agenda arrived rather late, because of the slow implementation of its liberalising reforms. However, domestic electoral politics also played a role, even though stakeholders tend to downplay this element. Apart from the initiation of TASAF in year 2000, the correlation between roll-out and elections may not always have been evident in the early years. However, it is worth keeping in mind that the continued insistence on community-driven projects in the early phases not only benefited the local populations, through new infrastructure, and the local poor, through work programmes, but also potentially provided a platform to connect to local officials and politicians, long almost entirely controlled by CCM, and for them to hand out benefits to potential voters. This type of semi-formalised patronage has been an element in Tanzanian politics since independence (Kelsall et al., 2005). Whereas the first PRSP, which included TASAF, was linked to larger debt relief initiative, which testifies to a strong transnational influence, the domestic political agenda became stronger as electoral completion increased during the 2000s and in particular during the 2010s.

In particular, the implementation of TASAF III with its PSSN element conspicuously correlated with the upcoming 2015 elections, a period of unprecedented political competition in Tanzania. Under the scale-up of PSSN, the identification of the beneficiaries was completed halfway through 2015, when the electoral activities set in, well before the elections on 25 October 2015. By December 2015, all 1.1 million households had been paid by the cash transfer programme, which was quite a feat in a country where payments from the public purse are notoriously delayed, and in a year which ended with rapidly increasing arrears to domestic private suppliers (IMF, 2015). Though politically useful, the lack of co-financing for TASAF III can be seen as a sign of limited general government commitment to the PSSN element in TASAF III that targets the poorest of the poor. Though the World Bank money for TASAF III is a credit, and therefore technically the country's own money, there is a greater willingness to spend money on interventions that are not core CCM priorities when it comes from development partners. According to the development partners, the government simply stated that it had no money. Indeed, when the new president took power, he inherited substantial deficits and arrears. However, his government has in fact begun a number of large infrastructure projects using government money.

Development partners were well aware that a large cash transfer programme could be used politically, and therefore stressed the need to separate the identification of beneficiaries from the election campaign, which started in mid-2015:

'Cash transfers are a good political tool. You can use it to buy political support. So we did not want certain political parties to use it to target their 
voters - we wanted the targeting to be completed before the elections period started. ${ }^{15}$

This focus on procedures is, however, questionable in a Tanzanian context, because it does not take into consideration the peculiar intertwining of Tanzanian politics and service delivery, where the ruling party targets the population at large with a certain emphasis on the rural majority, rather than more personalised handouts (O'Gorman, 2012; Kjær and Therkildsen, 2013). Luckily for the ruling party, its electorate and the rural majority largely overlap, which renders this strategy quite effective. In this respect, it is worth pointing to the peculiarities of Tanzania's political, economic and administrative set-up, which has been pointed to as more 'statist' than many other African countries (Boone, 2014; Boone and Nyeme, 2015; Pedersen and Jacob, 2017). This means that an element like ethnicity plays a smaller role, and struggles over resources to a larger extent play out in national institutions. This does not mean that neopatrimonial politics does not play a role in Tanzania, but that it takes other, more semi-formal, forms than elsewhere. In other words, there is little evidence suggesting that the identification of beneficiaries is influenced by electoral politics. ${ }^{16}$ Instead, we would argue that it is the timing of implementation that matters. Recently, Zitto Kabwe, an opposition politician, has also pointed to the use of cash transfer payments before a local government election. ${ }^{17}$ More research into these local political dynamics is needed.

In other words, whereas the design of the programme may have been more influenced by the policy coalition of bureaucrats and TASAF staff, the priorities of the ruling politicians to a larger extent appear during implementation. Furthermore, as outlined in the section on the gradual change of thinking within CCM above, a shift in priorities has been underway for some time. With the new administration's focus on productive investments, the CCM classic emphasis on self-reliance and hard work has only increased. This also reflects the president's personal preferences, which tend to be less generous towards vulnerable groups, hence the repeated remarks that 'lazy' people should not benefit from relief aid in hunger-stricken areas (Citizen, 2016; Guardian, 2017). The new president has now set his eyes on the cash-transfer elements of TASAF III, which, according to what development partner representatives are being told by their colleagues in the government, he does not

\footnotetext{
${ }^{15}$ Interview, 19 January 2018.

${ }^{16}$ Stakeholders are proud of the targeting, which is among the best in the developing world (see, for instance, World Bank and Tanzania Bureau of Statistics 2016). The identification of beneficiaries is based on needs assessments and is controlled during the process. This takes place through a three-stage system; first, the poorest districts, wards and communities are selected; secondly, within communities a preliminary list of the most poor and vulnerable households is prepared; finally, a means test is applied to eligibility (World Bank and Tanzania Natural Bureau of Statistics, 2016).

${ }^{17}$ On 11 August 2018, Kabwe tweeted: 'Yesterday and today TASAF money is being distributed to the poor. A day before election to elect a Ward councilor in Bugarama, Msalala District Council. @WBTanzania'.
} 
like: 'The government wants to turn it upside down, so that there will be not cash transfer and only public works' ${ }^{18}$

Given Tanzania's strong presidency and the further centralisation of power under the current one, this development has weakened the policy coalition of technocrats and development partners that propagated PSSN. Development partners and TASAF staff worry about the future of PSSN. Staff can tell stories about increased scepticism towards everything that may look like transfers when talking to colleagues in the government working groups. As a development partner puts it, it changes the debate by strengthening the latter's proponents:

'Now the President's remarks give the sceptics within the bureaucracy a platform for their views because it is coming from the very top. It is the power of the president in Tanzania that what he says is considered a policy'. ${ }^{19}$

Technocrats and development partners therefore worry about how they frame their interventions: 'We have to be careful with the language that we use. If we say we will expand CCT.... we have to be careful to save CCT'. ${ }^{20}$

Whereas one cannot conclude that the present signals mark a paradigm shift in the ruling party's attitude towards social protection in general, it does indicate a return towards a version with a bigger emphasis on the self-reliance of individuals and communities.

\section{Conclusion}

The introduction of TASAF, with its community initiatives and public work elements around year 2000, and TASAF III, with its (PSSN cash transfer elements rolled out from 2012 onwards, was strongly influenced by international trends. The initial TASAF programme was strongly linked to the poverty alleviation efforts in the wake of structural adjustment, and the PSSN linked to the Millennium Development Goal 1, to reduce poverty by half by 2015 . However, its design and implementation are also significantly influenced by Tanzania's domestic political economy. Thus, the introduction of TASAF correlated with President Mkapa's wish to stress the social dimension of structural adjustment, in the light of growing dissatisfaction in the populace. In other words, even if TASAF II and II to a large extent may have been carried out by a policy coalition of bureaucrats and development donors, its implementation also reflected political priorities at the time. This can also be seen in the initial programme's community-driven infrastructure projects, which mirrored a decade-old CCM emphasis on self-reliance over social handouts, and which furthermore could serve to strengthen CCM through the party's cadres' control over resources at the local level.

\footnotetext{
18 Interview with development partner representative, 19 January 2018.

${ }^{19}$ Interview with development partner representative, 15 January 2018.

${ }^{20}$ Ibid.
} 
The expansion of TASAF with PSSN in TASAF III, with its more individualised approach, differed from the past emphasis on community-driven self-reliance. To some extent, this was driven by the policy coalition of bureaucrats and development partners presenting the intervention in a productivist language, as pointed out by Ulriksen (2016), but it is also worth noting the time at which it happened. Firstly, it took off at a time when CCM was still shocked by the election results of 2010 and in the midst of a rethink of the party's future and its economic development model. Secondly, at the same time, there were rising expectations of revenues from the large gas deposits that had been found. Thirdly, government commitment was a prerequisite for the release of significant donor funds, which is always a priority in Tanzania. Finally, the massive scale-up of PSSN decided by the government prior to the 2015 elections is hardly a coincidence. Implementation happened with record speed just prior to the elections. However, the fact that the government never released the funds it had promised for TASAF III suggests that, even though the programme could be used for political ends, it was not a major CCM and government priority.

This suggests a good deal of opportunism in the ruling political elites' approach to TASAF and PSSN. Rather than emphasising transnational influence over domestic political economy, it suggests that both play a role, but that their mix has varied over time. The policy coalition of bureaucrats and development partners is unlikely to have pushed through the programmes without the explicit acceptance of the ruling political elites. The new President Magufuli's more recent productivist ethos, which poses a threat to the continuation of the PSSN element of TASAF III, marks a return to a more classical CCM emphasis on self-reliance. The emphasis on public work may furthermore reduce the individualised approach to social protection that was embodied in cash transfers, and encourage more community-driven interventions. It may furthermore reduce PSSN's targeting of the poorest of the poor, because some of those currently enrolled in the programme are not able to work. The president's concurrent efforts to recentralise decision-making after decades of decentralisation reflects the fact that the ruling party has lost control over many local government councils in recent elections (Tidemand, 2015; Mtulya, 2016). Combined, recentralisation and community-driven development means that CCM again appears as the main provider of benefits to the rural majority that makes up the core of its electoral base, more than the rural poor. 


\section{References}

Abel-Smith, B. and Rawal, P. (1992). 'Can the poor afford "free" health services? A case study of Tanzania'. Health Policy and Planning, 7: 329-341.

ADE, ITAD and COWI (2013). Joint Evaluation of Budget Support to Tanzania: Lessons Learned and Recommendations for the Future. Hove, UK: ITAD.

Awortwi, N. (2018). 'Social protection is a grassroots reality: Making the case for policy reflections on community-based social protection actors and services in Africa'. Development Policy Review.

Bakari, C. (2017). 'TASAF project reaches 70\% poor households'. Daily News, 12 December 2017.

Bates, R. (1981). Markets and States in Tropical Africa. Berkeley, CA:_University of California Press.

Bech, M. M., Lawi, Y. Q., Massay, D. A. and Rekdal, O. B. (2013). 'Changing policies and their influence on government health workers in Tanzania, 1967-2009: Perspectives from rural Mbulu District'. International Journal of African Historical Studies, 46: 61-103.

Beegle, K., Coudouel, A. and Monsalve, E. (2018). Realizing the Full Potential of Social Safety Nets in Africa. Washington, DC: World Bank.

Bienen, H. (1967). Tanzania. Party Transformation and Economic Development. Princeton, NJ: Princeton University Press.

Bjerk, P. (2017). Julius Nyerere. Athens, OH: Ohio University Press.

Boone, C. (2014). Property and Political Order in Africa. Land Rights and the Structure of Politics. New York: Cambridge University Press.

Boone, C. and Nyeme, L. (2015). 'Land institutions and political ethnicity in Africa: Evidence from Tanzania'. Comparative Politics 48(1): 67-86.

Carlitz, R. (2011). 'Quantity without quality? Rethinking education goals', Budget Brief No. 8. The International Budget Partnership (IBP).

CCM (2005). 'Ilani ya Uchaguzi ya CCM kwa ajili ya Uchaguzi Mkuu wa 2005'. Dodoma, Tanzania.

CCM (2010). 'Ilani ya Uchaguzi ya CCM kwa ajili ya Uchaguzi Mkuu wa 2010'. Dodoma, Tanzania.

CCM (2015). 'Ilani ya Uchaguzi ya CCM kwa ajili ya Uchaguzi Mkuu wa 2015'. Dodoma, Tanzania.

Chimhutu, V., Tjomsland, M., Songstad, N. G., Mrisho, M. and Moland, K. M. (2015). 'Introducing payment for performance in the health sector of Tanzania - the policy process'. Globalization and Health, 11: 38.

Citizen, T. (2016). 'No food for lazy people, JPM warns'. The Citizen, 11 August.

Cliffe, L. (1967). 'Arusha Declaration. Challenge to Tanzanians'. East Africa Journal, March..

Cooksey, B. (2011). 'Public goods, rents and business in Tanzania'. Africa Power and Politics. Background Paper. London: ODI.

Daily News (2012). 'Nape rubbishes CCM downfall talk'. Daily News, 28 March.

Daily News (2018). 'Projects big job creators...30,000 to get direct employment and 600,000 will be indirect beneficiaries'. Daily News, 15 March. 
Daima Associates and ODI (2005). Joint Evaluation of General Budget Support Tanzania1995-2004. Revised final report.

Davis, B., Handa, S., Hypher, N., Rossi, N. W., Winters, P. and Yablonski, J. (2016). From Evidence to Action: The Story of Cash Transfers and Impact Evaluation in Sub-Saharan Africa. Oxford: Oxford University Press.

Di John, J. and Putzel, J. (2009). 'Political settlements: Issues paper'. Birmingham, UK: University of Birmingham.

Edwards, S. (2014). Toxic Aid. Economic Collapse and Recovery in Tanzania. Oxford: Oxford University Press.

Frigenti, L., Harth, A. and Huque, R. (1999). 'Social funds and public works and employment projects in Sub-Saharan Africa'. African Region Findings and Good Practice Infobriefs, No. 37. Washington, DC: World Bank

Gibbon, P. E. (1995). Liberalised Development in Tanzania. Uppsala: Nordiska Afrikainstitutet.

Gould, J. and Ojanen, J. (2005). 'Tanzania: Merging in the circle'. In Gould, J. (ed.), The New Conditionality: The Politics of Poverty Reduction Strategies. London: Zed Books.

Guardian (2017). 'No relief food for lazy people, VP Samia reiterates'. Guardian, 9 August.

Guardian (2018). 'Villagers in Kilwa District seek Tasaf enrolment'. Guardian, 17 January.

Havnevik, K. and Isinika, A. (2010)_. Tanzania in Transition. From Nyerere to Mkapa. Dar es Salaam: Mkuki na Nyota.

Holtom, D. (2007). 'The challenge of consensus building: Tanzania's PRSP 19982001'. The Journal of Modern African Studies, 45:, 233-251.

Hyden, G. (1975). 'Ujamaa, villagisation and rural development in Tanzania'. Development Policy Review, 8: 53-72.

Hyden, G. (1990). 'Responses from below: a tale of two Tanzanian villages'. Food Policy, 15: 299-305.

IMF (2015). 'United Republic of Tanzania: Second review under the policy support instrument'. Country Report No. 15/181. IMF Africa Department.

IMF and International Development Association (2002). Review of the Poverty Reduction Strategy Paper (PRSP) Approach: Early Experience with Interim PRSPs and Full PRSPs. Prepared by the staffs of the IMF and World Bank. 26 MarchWashington, DC: IMF.

Ingle, C. R. (1970). 'Compulsion and rural development in Tanzania'. Canadian Journal of African Studies, 4:77-100.

International Federation of Red Cross and Red Crescent Societies (2006). 'Tanzania drought'. Operations Update, 7 August. International Federation of Red Cross and Red Crescent Societies.

Jacob, T. and Pedersen, R. H. (2018). 'New resource nationalism? Continuity and change in Tanzania's extractive industries'. The Extractive Industries and Society 5(2): 287-292.

Jennings, M. (2008). Surrogates of the State: NGOs, Development and Ujamaa in Tanzania. Bloomfield, CT: Kumarian Press. 
Jennings, M. (2015). 'The precariousness of the franchise state: Voluntary sector health services and international NGOs in Tanzania, 1960s-mid-1980s'. Social Science and Medicine, 141: 1-8.

Kamndaya, S. (2017). 'Shift provides parastatals big role in projects'. The Citizen, 9 June.

Kelsall, T., Lange, S., Mesaki, S. and Mmuya, M. (2005). Understanding Patterns of Accountability in Tanzania. Component 2: The Bottom-up Perspective.

Oxford: Oxford Policy Management.

Khan, M. H. (2010). Political Settlements and the Governance of Growth-Enhancing Institutions. Available online: https://eprints.soas.ac.uk/9968/1/Political_Settlements_internet.pdf.

Khan, M. H. and Gray, H. (2006). 'State weakness in developing countries and strategies of institutional reform: Operational implications for anti-corruption policy and a case study of Tanzania'. Discussion paper. London: Department for International Development.

Kiganda, A. (2016). 'Construction of 10,000 housing units for defense forces of Tanzania launched'. Construction Review Online.

Kimambo, I., Temu, A. J. (eds.) (1969). A History of Tanzania. Nairobi: East African Publishing House.

Kimambo, Maddox, G. H. and Nyanto, S. S. (2017). A New History of Tanzania, Dar es Salaam: Mkuki na Nyota.

Kjær, A. M. and Therkildsen, O. (2013). 'Elections and landmark policies in Tanzania and Uganda'. Democratization 20(4): 592-614.

Lavers, T. and Hickey, S. (2016). 'Conceptualising the politics of social protection expansion in low income countries: The intersection of transnational ideas and domestic politics'. International Journal of Social Welfare, 25: 388-398.

Lofchie, M. F. (2014). The Political Economy of Tanzania: Decline and Recovery, Philadelphia, PA: University of Pennsylvania Press.

Lugalla, J. L. P. (1993). 'Structural adjustment policies and education in Tanzania', in: Gibbon, P. (ed.), Social Change and Economic Reform in Africa. Uppsala: Nordiska Afrikainstitutet.

Maclean, L. M. (2010). Informal Institutions and Citizenship in Rural Africa: Risk and Reciprocity in Ghana and Côte d'Ivoire. New York: Cambridge University Press.

Mallya, E. T. (2012). 'Dealing with conflict of interest: Separating business from politics in Tanzania'. Journal of Education, Humanities and Sciences 1(1).

Marcus, R., Piron, L. H., and Slaymaker, T. (2004). 'Basic services and social protection'. Thematic contribution to DFID Position Paper on Social Protection.

Mashindano, O. and Maro, F. (2011). Growth without Poverty Reduction in Tanzania: Reasons for the Mismatch. Dar es Salaam: ESRF, Chronic Poverty Research Centre.

Mbekeani, K. (2009). 'Health sector reforms: Tanzania's health policy strategy to increase access to care and improve health'. Medicine and Law, 28, 167-179. 
Mkapa, B. (2002). Opening speech by the chairman of Chama Cha Mapinduzi (CCM), His Excellency President Benjamin William Mkapa, at the Sixth Ordinary CCM National Congress, Chimwaga - Dodoma, 29 October.

Mkapa, B. (2013b). 'Human development and poverty reduction (1997)'. In: SEFUE, O. (ed.), The Mkapa Years. Collected Speeches Volume 1: Challenges and Policy Responses. Dar es Salaam: Mkuku Na Nyota.

Mkapa, B. (2013c). 'Launch of the workshop for the Tanzania Social Action Fund (TASAF) (2000)'. In: Sefue, O. (ed.), The Mkapa Years. Collected Speeches Volume 3: Governance, Policy and Institutional Reform and Platform for the Future. Dar es Salaam: Mkuku Na Nyota.

Mkinga, M. (2013). 'Handeni might starve to death if it doesn't get 17000 tonnes of food aid'. The Citizen, 29 March.

Morriseey, O. and Leyaro, V. (2009). 'Tanzania'. In: Anderson, K. and Masters, W. A. (eds.), Distortions to Agricultural Incentives in Africa. Washington, DC: World Bank.

Morrisson, C. (2002). Education and Health Expenditure and Poverty Reduction in East Africa: Madagascar and Tanzania. Paris: OECD Publishing.

Mpango, P. (2017). Bunge la Tanzania: Majadiliano ya Bunge, Mkutano wa Saba/National Assembly of Tanzania: Parliamentary Discussion, Seventh Session, 44th sitting. 8 June.

Msekwa, P. (2017). Reflections on CCM's history of re-branding itself: The story of "CCM kujivua gamba" re-branding in 2011'. Daily News, 2 February.

Msekwa, P. (2017). 'CCM endorses sweeping reforms:: Trims numbers of members in decision making organs'. Daily News, 23 March.

Mtulya, A. (2016). 'Ignore CCM manifesto at your peril, govt. workers warned'. The Citizen 24 July.

Mukandala, R. S. (1989). The Political Economy of Parastatal Enterprise in Tanzania and Botswana. PhD thesis, University of California, Berkeley.

Munishi, G. K. (1995). 'Social services provision in Tanzania: The relationship between political development strategies and NGO participation'. In: Semboja, J. and Therkildsen, O. (eds.), Service Provision under Stress in East Africa: The State, NGOs and People's Organizations in Kenya, Tanzania and Uganda. Copenhagen: Centre for Development Research.

Munishi, G. K. (1997). Private Health Sector Growth Following Liberalization in Tanzania: Some Policy Considerations. Nonthaburi, Thailand: International Health Policy Program.

Nyaluke, D. and Connolly, E. (2013). 'The role of political ideas in multi-party elections in Tanzania: Refuting essentialist explanations of African political systems'. Irish Studies in International Affairs 24:1-17.

Nyerere, J. K. (1967). The Arusha Declaration.

O'Gorman, M. (2012). 'Why the CCM won't lose: The roots of single-party dominance in Tanzania'. Journal of Contemporary African Studies, 30: 313-333.

Odunga, M. (2016). 'Military forces to get closer state support', Daily News, 1 October.

Paget, D. (2017). 'Tanzania: Shrinking space and opposition protest'. Journal of Democracy, 28. 
Pedersen, R. H. and Jacob, T. (2017). 'Reconfigured state-community relations in Africa's extractive sectors: Insights from post-liberalisation Tanzania'. The Extractive Industries and Society, 4, 915-922.

Pedersen, R. H. and Jacob, T. (2018, forthcoming). 'Social protection in an electorally competitive environment (2): The politics of health insurance in Tanzania'. ESID Working Paper. Manchester: Effective States and Inclusive Development Research Centre, The University of Manchester.

Reddy, S. (1998). 'Social funds in developing countries: Recent experiences and lessons'. UNICEF Staff Working Papers, Evaluation, Policy and Planning Series No. EPP-EVL-98-002. New York: Unicef.

Schneider, L. (2004). 'Freedom and unfreedom in rural development: Julius Nyerere, Ujamaa Vijijini, and villagisation: Canadian Journal of African Studies, 38:344-392.

Schneider, L. (2006). 'Colonial legacies and postcolonial authoritarianism in Tanzania: Connects and disconnects'. African Studies Review, 49: 93-118.

Selbervik, H. (2006). PRSP in Tanzania: Do Mkukuta and the CCM Election Manifesto Pull in the Same Direction? CMI Report 2006: 9. Bergen: Chr. Michelsen Institute.

Sembony, G. (2009). 'Tanzania: Government sends seeds to district hit by drought'. The Citizen.

Silver, M. S. (1984). The Growth of Manufacturing Industry in Tanzania: An Economic History, Boulder, CO: Westview Press.

TASAF (2011). 'TASAF: Project to Program'. Presentation at TFESSD Learning Form, Kunduchi Beach Hotel and Resort, 15-17 November, Dar es Salaam.

Therkildsen, O. (2000). 'Public sector reform in a poor, aid-dependent country, Tanzania'. Public Administration and Development, 20: 61.

Therkildsen, O. and Bourguin, F. (2012). 'Continuity and change in Tanzania's ruling coalition: Legacies, crises and weak productive capacity'. DIIS Working Paper. Copenhagen: Danish Institute for International Studies.

Tidemand, P. (2015). 'The political economy of local government reforms in Tanzania. Perspectives on politics, production and public administration in Africa'. In A. M. Kjær, L. Pedersen, Engberg and L. Buur (eds.), Essays in Honour of Ole Therkildsen pp. 69-86.

Tripp, A. M. (2000). 'Political reform in Tanzania: The struggle for associational autonomy'. Comparative Politics, 32(2): 191-214.

Tsubura, M. (2017). "'Umoja ni ushindi (Unity is victory)”: Management of factionalism in the presidential nomination of Tanzania's dominant party in 2015'. Journal of Eastern African Studies 12(2): 1-20.

Ulriksen, M. S. (2016). 'The development of social protection policies in Tanzania, 2000-2015'. CSSR Working Paper No. 377. Cape Town: Centre for Social Science Research, University of Cape Town.

URT, United Republic of Tanzania (1990). National Health Policy.

URT, United Republic of Tanzania (1995). Education and Training Policy.

URT, United Republic of Tanzania (2000a). Poverty Reduction Strategy paper (PRSP). 
URT, United Republic of Tanzania (2000b). The Tanzania Development Vison 2025. Available online: http://www.mof.go.tz/mofdocs/overarch/vision2025.htm (accessed 5 November 2018). Dar es Salaam: Planning Commission.

URT, United Republic of Tanzania (2011). The Tanzania Five Year Development Plan 2011/2012-2015/2016. Unleashing Tanzania's Latent Growth Potentials. Available online: http://extwprlegs1.fao.org/docs/pdf/tan151051.pdf (accessed 5 November 2018). Dar es Salaam: President's Office, Planning Commission.

USAID (2016). 'Health financing profile. Tanzania, May 2016'. Washington, DC: Health Policy Project.

Vavrus, F. and Moshi, G. (2009). 'The cost of a "free" primary education in Tanzania'. International Critical Childhood Policy Studies Journal, 2: 31-42.

West-Slevin, K. and Dutta, A. (2015). Prospects for Sustainable Health Financing in Tanzania: Baseline Report. Washington, DC: Health Policy Project, Futures Group.

World Bank (2006). Tanzania: Social Action Fund Project. Washington, DC: World Bank.

World Bank (2014). Tanzania: Second Social Action Fund. Washington, DC: World Bank.

World Bank and Tanzania National Bureau of Statistics (2016). Tanzania's Productive Social Safety Net. Findings from the Impact Evaluation Baseline Survey. Washington, DC: World Bank.

World Bank (2017). Productive Social Safety Net: Implementation Status and Results Report. Washington, DC: World Bank.

World Bank (2018). World Bank data bank on health in Tanzania, online resource: https://data.worldbank.org/indicator/SH.XPD.EHEX.CH.ZS?locations=TZ (accessed 27 January 2018). 


\section{esid}

\section{The Effective States and Inclusive Development Research Centre}

The Effective States and Inclusive Development Research Centre (ESID) aims to improve the use of governance research evidence in decision-making. Our key focus is on the role of state effectiveness and elite commitment in achieving inclusive development and social justice.

ESID is a partnership of highly reputed research and policy institutes based in Africa, Asia, Europe and North America. The lead institution is the University of Manchester.

The other institutional partners are:

- $\quad$ BRAC Institute of Governance and Development, BRAC University, Dhaka

- $\quad$ Center for Democratic Development, Accra

- $\quad$ Center for International Development, Harvard University, Boston

- Department of Political and Administrative Studies, University of Malawi, Zomba

- $\quad$ Graduate School of Development, Policy \& Practice, Cape Town University

- Institute for Economic Growth, Delhi

In addition to its institutional partners, ESID has established a network of leading research collaborators and policy/uptake experts. 